
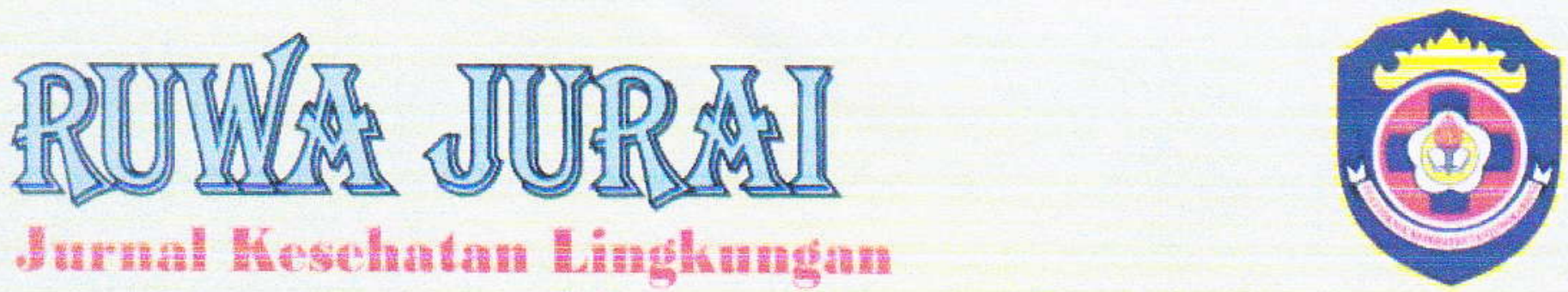

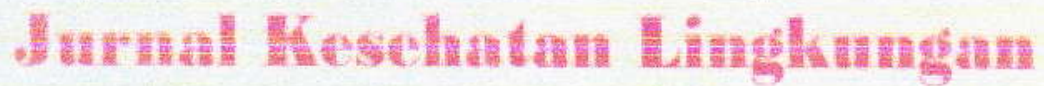

Volume 12, Nomor 1, Juni 2018

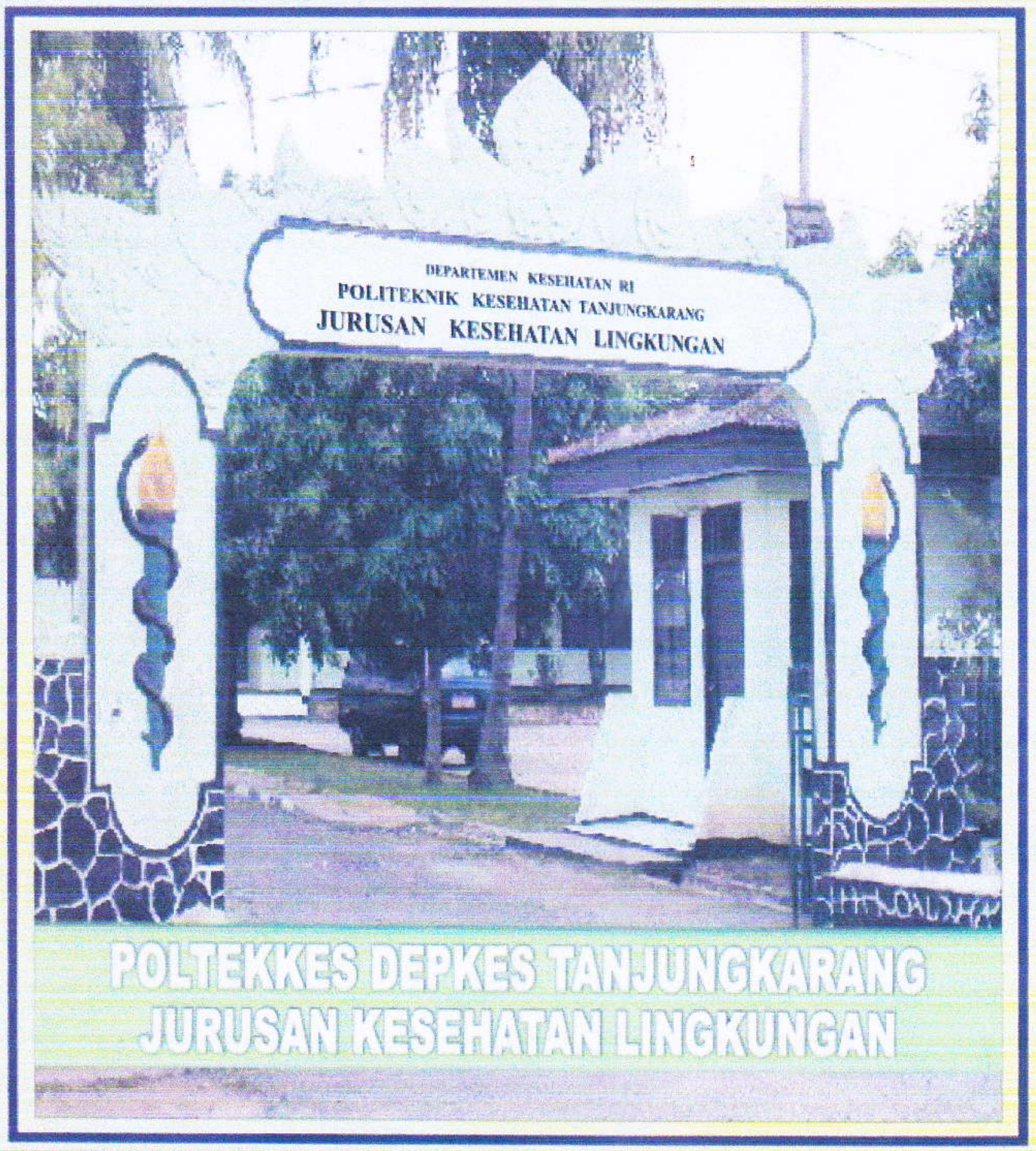

Diterbitkan Oleh :

Jurusan Kesehatan Lingkungan Politeknik Kesehatan Tanjungkarang Jalan Raya Hajimena No. 100 Telp. (0721) 703630, Fax (0721) 787501 

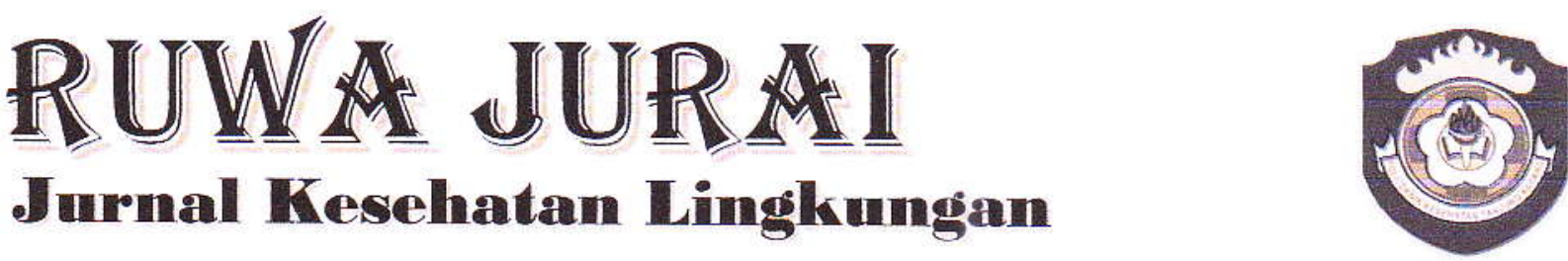

Volume 12, Nomor 1, Juni 2018

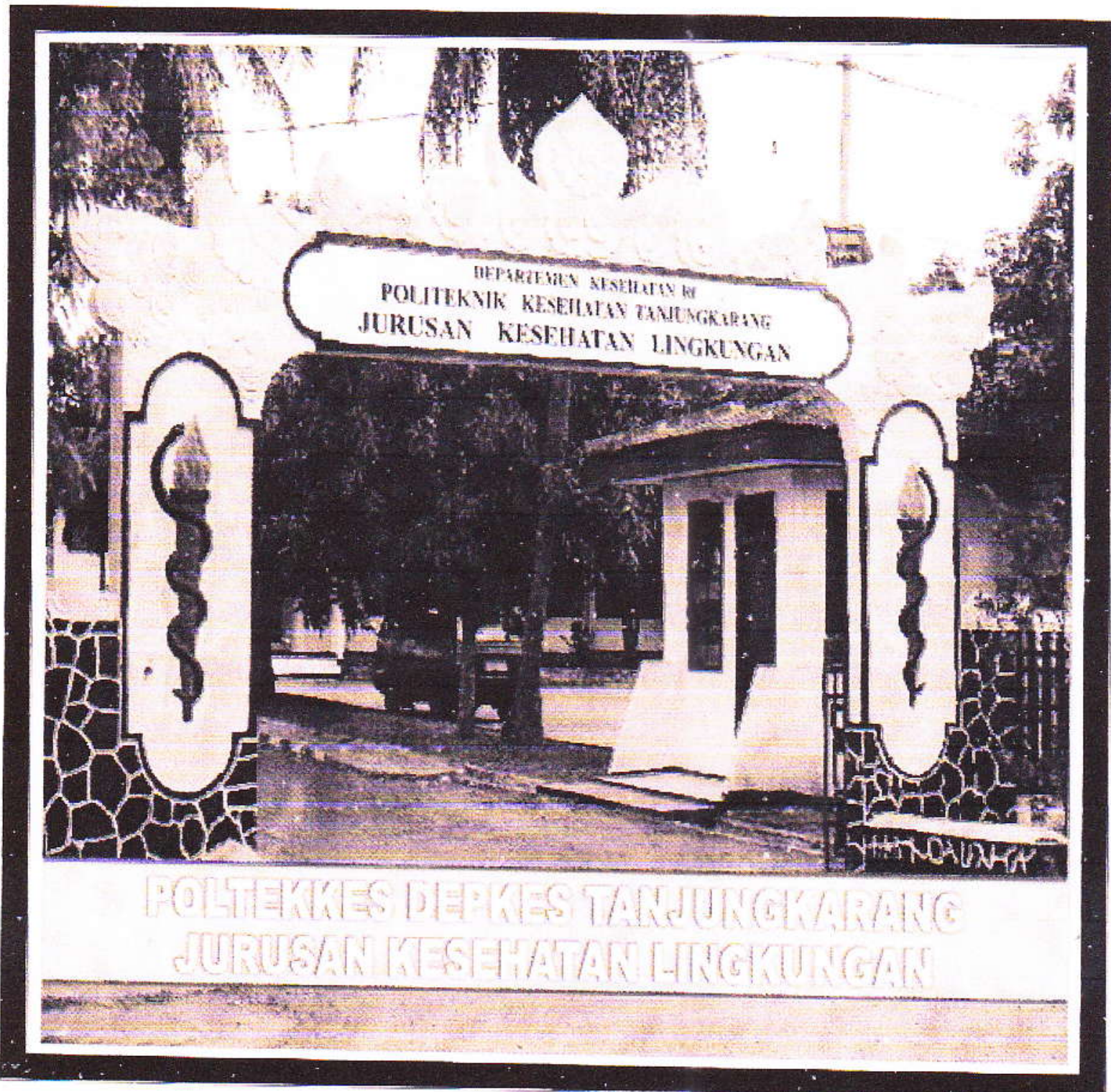

Diterbitkan oleh :

Jurusan Kesehatan Lingkungan Politeknik Kssehatan Tanjungarang Jalan Raya hajimena No. 100 Telp (0721) 703630, Fax (0721) 787501

BANDAR LAMPUNG 


\section{RUWA JURAI}

Jurnal Kesehatan Lingkungan

\section{Penerbit}

Jurusan Kesehatan Lingkungan

Politeknik Kesehatan Kemenkes

Tanjungkarang

\section{Dewan Redaksi}

Pembina/Penasehat :

Direktur Politeknik Kesehatan Kemenkes

Tanjungkarang

\section{Penanggung Jawab:}

Ketua Jurusan Kesehatan Lingkungan

Pimpinan Redaksi :

Karbito

Wakil Pimpinan Redaksi :

Ahmad Fikri

Sekretaris :

Suami Indarwati

\section{Redaksi :}

Purwono

Wibowo Ady Sapta

Sarip Usman

Zainal Muslim

Enro Sujito

\section{Redaksi Pelaksana :}

Imam Santosa

Agus Sutopo

Daria Br Ginting

Himpunan Mahasiswa Jurusan

\section{Editing :}

Karbito

Ahmad Fikri

Suami Indarwati

Selfi Octaviani Lestari

Winalia

\section{DAFTAR ISI}

Pengantar Redaksi

Hubungan Konstruksi, Jenis dan Jarak Wadah Sampah dengan Kepadatan Lalat Pada Kantin Sekolah Dasar di Kecamatan Way Jepara Kabupaten Lampung Timur

Satria Tri Wibowo

Efektivitas Koagulan terhadap Penurunan Parameter Limbah Cair Industri tahu

Dewi Anggarwati

$9-16$

Hubungan Sarana Sanitasi Dengan Kejadian Diare Pada Balita di Kelurahan Way Laga Kecamatan Sukabumi Kota Bandar Lampung

Fadila Dwi Anjani

Tanaman Apu-apu Dalam menurunkan Kadar Limbah Rumah Sakit

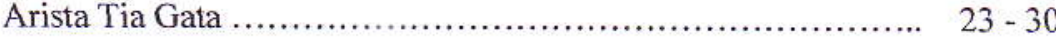

Efektivitas Ekstrak Biji Pepaya (Carica papaya Linnaeus) Sebagai Larvasida Pada Larva Aedes aegypti Instar III

Jelita Mahdalena Isra

$31-36$

Pemanfaatan Sampah Organik Pasar Sebagai pakan Ikan Fajar Febri Patriatama

Faktor-faktor Yang Berhubungan Dengan Kejadian DBD di Wilayah Kerja Puskesmas Ambarawa Kabupaten Pringsewu Provinsi Lampung 2017

Diantika Pratiwi 


\section{Pengantar Redaksi}

Puji dan syukur atas segala nikmat yang telah Allah SWT berikan kepada kita semua sehingga di tengah tahun ini masih dapat bertemu kembali dengan informasi terkini seputar ilmu pengetahuan dan teknologi dibidang kesehatan lingkungan.

Jurnal Kesehatan Lingkungan "RUWA JURAI" Volume 12, Nomor 1, Juni 2018 hadir dengan menyajikan informasi ilmu pengetahuan, inovasi teknologi dan solusi tentang permasalahan lingkungan yang berkembang dewasa ini. Harapan kami, terbitnya Jurnal ini dapat lebih meningkatkan wawasan dan semangat diri untuk berkarya demi kemajuan ilmu pengetahuan dan teknologi.

Terima kasih kami ucapkan kepada pembaca yang budiman atas dukungan dan apresiasinya terhadap Jurnal ini. Kritik dan saran juga senantiasa kami tunggu guna koreksi dan kesempurnaan Jurnal pada penerbitan mendatang.

Tim Redaksi 